\title{
Causal Factors and Effects of Unemployment on Graduates of Tertiary Institutions in Ogun State South West Nigeria: Implications for Counselling
}

\author{
Assoc. Prof. (Mrs.) Anna Onoyase \\ Department of Guidance and Counselling, \\ Delta State University, \\ P.M.B. 1, Abraka, Delta State, Nigeria
}

Doi: 10.36941/jesr-2019-0014

\begin{abstract}
The research was set out to find the causal factors and effects of unemployment on graduates of tertiary institutions in Ogun State South West Nigeria: Implications for counselling. In order to carry out the research, two research questions and one hypotheses were formulated to guide the study. The researcher made use of an instrument tagged causal factors and effects of unemployment on graduates of tertiary institutions questionnaire (CFAEOUGOTIQ) to collect information. The instrument contained twenty items. The instrument had content validity and language appropriateness. The instrument had a reliability coefficient of 0.85 . The population of the study was made up of graduates of universities, polytechnics and colleges of education that had no job in public and private sectors in Ogun State Nigeria. The researcher used the purposive sampling technique to select 226 university graduates, 120 polytechnic graduates and 75 college of education graduates that participated in the research. Copies of the questionnaire were administered on each of the participants by 3 research assistants. The return rate of copies of the questionnaire administered, showed that 215 questionnaires were retrieved from the university graduates, 107 questionnaires were retrieved from polytechnic graduates and 60 copies of the questionnaire were retrieved from college of education graduates. The scoring and collation of the information from the field was done by the researcher. The researcher used the mean and standard deviation to answer the two research questions while the analysis of variance was used to test the hypothesis. The researchers used 2.50 as benchmark to determine whether respondents agreed or disagreed with each of the items on table one and two. The hypothesis was held significant at 0.05 level of significance. Some of the findings of the research showed that, high rate of graduate turn out, neglect of the agricultural sector by government, collapse of manufacturing industries and reforms in the banking sector resulting in regular retrenchment of workers were causal factor of unemployment on graduates of tertiary institutions. Other include, misappropriation of funds meant for development of projects, lack of employable skills by graduates and inability to pass employment interviews. The research also found out that one of the effects of unemployment on graduates of tertiary institution is low self-esteem of themselves. One of the recommendations is that admission into tertiary institutions should be based on the number of vacancies available in public and private sectors.
\end{abstract}

Keywords: Causal factors, effects, unemployment, tertiary institutions

\section{Introduction}

Today, the number of universities, both public and private keep on increasing. The same thing is true of polytechnics and colleges of education. In support of this, Egwunyenga (2018: 23) quoting Yusuf and Afolabi (2014), asserted, that higher education in Nigeria since inception in 1932, with the establishment of Yaba Higher College and later Yaba College of technology in 1947, higher 
education institutions have grown rapidly from 02 to over 365, comprising over 122 universities, 74 polytechnics and 80 colleges of education. Each year, the institutions keep on graduating into already saturated labour market.

\section{Review of Related Literature}

Safyanu and Alimburza (2011: 11) opined that graduates of tertiary institutions face the difficulty of not readily getting jobs immediately after school. Sara (2008), and Tandama (2009), researches have revealed that some years back, graduates of tertiary institutions easily got employed after they have graduated from school. Their researches revealed that the situation drastically became difficult as the number of graduates continue to soar, coupled with the shortage of vacancies. This development, according to Sara and Tandama has forced graduates of tertiary institutions in Nigeria to go in search of self- employment.

Longe (2017: 63), has lamented that in Africa and in Nigeria in particular, graduates unemployment is a very daunting challenge in the labour market. Balogun (2016: 63), stressed that almost half of the 10 million graduates turned- out of over 668 universities in Africa yearly do not get jobs. Safyanu and Alimburza (2011: 12), have stated that one of the reasons why graduates find it difficult to secure jobs after their graduation can be traced to inadequate curricula that their institutions have adopted. The daily Trust Newspaper (2018), reported that "securing employment can only be guaranteed if you are highly connected". Those that have people in positions of authority stand a better chance of being gainfully employed in the labour market. In otherwords, corruption is one of factors of graduates unemployment in Nigeria.

In Malaysia, Sirat and Shuib (2012) and Noor (2011) as quoted by Longe (2017: 65), have found out that job mis-match, English proficiency, misguided educational qualification and lack of employable skills were held as factors responsible for university graduates unemployment. The reason given by Madoui (2015) as responsible for graduates unemployment in Algeria is the disconnection between university education system and the world of work. Madoui maintained that the skills that are gotten from the higher institutions appeared to be dysfunctional and not relevant. Some university graduates therefore found themselves in problems as a result of the gap in the skills they got from the university and skills demanded by employers of labour in Algeria.

Naong (2011) has asserted that many of the graduates in South Africa often battle to get employment because of the wrong field of study chosen by them. This, in-addition to the high rate of graduate turn-out often lead to unemployment of graduates in South Africa. It may be correct to say "that South Africa, Greece and Nigeria are the countries where you have the highest rate of graduate unemployment in the world". In Nigeria, the unemployment rate as reported by the National Bureau of Statistics increased from $20.10 \%$ in 2010 to $23.90 \%$ in 2011 . The unemployment between 2006 and 2011 average at $14.60 \%$. In 2006, it was 5.30\%. This however rose to $23.90 \%$ in December 2011.

Okpoko and Ughwufobe (2015:118) reported that as students graduate from institutions of high learning, they enter into a world of uncertainty, bleak employment opportunities and fear for an uncertain future. They maintained that this situation has plunged many unemployed school leavers into desperate attempts to secure jobs and some even die in the process. Not long ago, the Nigerian Immigration Board conducted a recruitment exercise for prospective job seekers. According to the Vanguard newspaper (2014), over 750,000 applied for the available 5,000 spaces. In their desperate attempt to secure these few jobs, some people were trampled to death while others collapsed in the race to select the fittest. People ran, got tired, but continued to run until they either fainted or collapsed and some died in the process.

Sara and Mburza (2011), opined the reason why graduates find it difficult to secure jobs after graduation may be traced to inadequate curriculum adopted by their institutions. They further claimed that graduates do not have appropriate job competencies required by their employers. Similarly, some of these graduates do not bring their personal traits to their search behaviour through adopting creative and innovative strategies that promote job creation and even security.

Okafor (2011), has stressed that corruption is one of the reasons, responsible for unemployment of graduates in Nigeria. He maintained, that corruption has deprived Nigeria of 
developing a strong economic base. Okafor opined that funds meant for development of projects have been misappropriated, diverted, embezzled and stashed away in foreign banks. Okafor (2011) lamented that there is no vibrant manufacturing sector that has the capacity to absorb unemployed youths in Nigeria.

Adesina (2013) has observed that over 800 collapsed industries in Nigeria and over 37 factories closed shops in 2009. He added that half of the remaining operating firms have been classified by Manufacturers Association of Nigeria (MAN) as "ailing", a situation that poses; a great threat to the survival of manufacturing in Nigeria. Adesina equally asserted that the banking subsector did not help matter. This is because the on-going, reforms and consolidation have sent several young men and women back into the labour market, instead of the sector generating employment. He opined that the manufacturing sector has not fared any better. For instance, the number of persons in the paid employment at the end of 2010 in the cement manufacturing subsector stood at 3,318 compared to 4,142 in 2009, a decline of $19.9 \%$.

Adekola, Allen, Olawole- Isaac, Akanbi and Adewumi (2016: 4), have identified the neglect of agricultural sector as one of the causes of graduate unemployment in Nigeria. The dependence of the country solely on the oil sector has made the young graduates to migrate from the rural areas to urban centres where they could get employment in oil companies.

\section{Effects of Graduate Unemployment}

Shadare and Elegbede (2012) have opined, that graduates unemployment as it is, in many developing countries, for instance, in Nigeria poses a problem to the labour market and the overall economy of the countries concerned. Madoui (2015) has asserted that apart from the fact that the unemployed graduate is deprived of earning salary, he is equally deprived of socialization effect of work and removed from social ties and relationship.

This is why in Nigeria and other third world countries, the unemployed graduate appears to experience shame, hardship and frustration. Madoui stated that the unemployed graduate is put in a situation of worklessness, a person that is dispossessed and having no income value in the society. Adawo, Essien and Ekpo (2012) stated that the unemployed graduate is unhappy with himself in the world of material consideration. Asmara and Mulate (2014), maintained that the unemployed is not socially recognized and this make some friends and relatives to look- down on them as liabilities in the society. This makes the unemployed graduates to exhibit a kind of nonconforming and negative social vices that are found in Nigeria today, for example, kidnappers.

Salami (2013), is of the opinion that Nigeria spiraling youth unemployment can be said to have significantly contributed to the dramatic rise in social unrest and crime such as Nigeria Delta militancy, Boko haram and Jos crisis. Aihie and Alika (2014), have observed that unemployment has negative effects on the unemployed, such as low self-esteem, frustration and depression. Unemployment may lead to anti-social behaviour such as prostitution in the females and arm robbery or kidnapping in males. Okiokio (2012), observed that youths in Nigeria constitute the bulk of unemployed searching for jobs where there is none.

\section{Definition of Terms}

Causal Factors: In this research, causal factors are defined to mean the reasons responsible for unemployment.

Tertiary Institutions: Refers to the educational institutions where students receive university, polytechnic and college of education instructions.

Graduates: In this research, graduates refer to those who have successfully completed their university, polytechnic and college of education programmes.

Public Sector: This refers to government ministries and parastals.

Private Sector: Is used in this research to mean corporate organisations like banks and manufacturing industries not owned by government. 


\section{Statement of the Problem}

As far back as 1960s, 1970s and 1980s, final year students of tertiary institutions in Nigeria, enjoyed wooing from employers of labour, both public and private sectors. As part of enticing the final years to work in their establishments, some bought beverages for them, made promise of provision of car loan and accommodation for them. Some employers of labour went from one tertiary institution to another to interview the final year students and gave them letters of employment so that they can resume work immediately after their examinations. Those were the good days when the vacancies were abundantly there.

But in the 1990s till date, the story is no longer what it used to be. No employer of labour goes from one institution to another to get final year students interviewed for jobs again. Beverages are no longer bought to entice the final year students. The graduates of tertiary institutions now go from one employer of labour to another to solicit for jobs. Only few of the great number that graduate from tertiary institutions get employed. The situation has become so bad that, there were some that have graduated for over fifteen years without jobs. The problem of this research put in a question is: what are the causal factors and effects of unemployment on graduates of tertiary institutions in Nigeria? Specifically, the research sought to answer the following questions:

1. What are the causal factors of unemployment among graduates of tertiary institutions in Ogun State, Nigeria?

2. What are the effect of unemployment on graduates of tertiary institutions in Ogun State, Nigeria?

\subsection{Hypothesis}

Ho: There is no significant difference among university, polytechnic and college of education graduates in their opinion about the effects of unemployment on graduates of tertiary institutions in Ogun State, Nigeria.

\section{Research Method and Procedure}

The Ex post facto design has been adopted for this research. This is the research that is undertaken after the events have occurred. Asika (2002: 24) has opined that Ex post facto research is a systematic empirical study in which the researcher does not in any way control or manipulate independent variables because the situation for the study already exists or has already taken place. The instrument used for the collection of data is the causal factors and effects of unemployment on graduates of tertiary institutions questionnaire (CFAEOUGOTIQ). The instrument had twenty items. The instrument had content validity and language appropriateness. The instrument had a reliability coefficient of 0.85 using the test - retest technique. The respondents were to tick $(\sqrt{ })$ strongly agreed $(S A)=4$, agreed $(A)=3$, Disagreed $(D)=2$, strongly disagreed $(S D)=1$.

The population of the research was made up of university, polytechnic and college of education graduates that had no employment in public and private sectors in Ogun State, Nigeria. The purposive sampling method was used to select 226, university graduates, 120 polytechnic graduates and 75 college of education graduates to whom the copies of the questionnaire were administered. Three research assistants were used to administer the questionnaire on the respondents in churches and mosques in Ogun State. From the 226 copies of the questionnaire administered on university graduates 215 were retrieved; out of the 120 copies of the questionnaire administered on polytechnic graduates, 107 were retrieved and from the 75 copies, of the questionnaire administered on the college of education graduates, 60 were retrieved. The scoring and collation of the information from the field were carried out by the researcher. The mean and standard deviation were used to answer the research questions while analysis of variance was used to analyse the hypothesis. The researcher used 2.50 as benchmark to determine whether respondents agreed or disagreed with each of the statements on table one and two. The hypothesis was tested at 0.05 level of significance. 


\section{Research Question 1}

What are the causal factors of unemployment among graduate of tertiary institution in Ogun State, Nigeria.

Table 1: Mean and standard deviation on the causal factors of unemployment among graduates of tertiary institutions. ( $\mathrm{N}=215$ University Graduate)

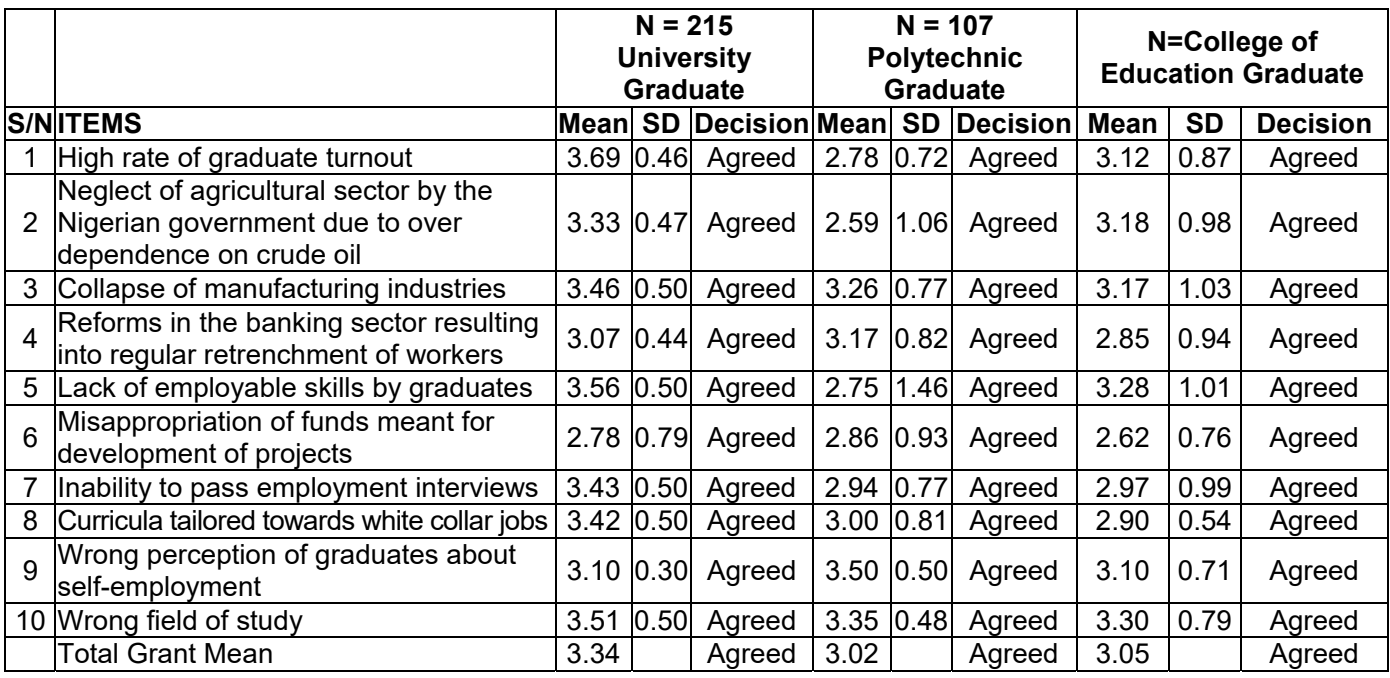

Table 1, showed that the respondents agreed to items 1-10 on the casual factors of unemployment among graduates of tertiary institutions in Nigeria. The university graduate have a mean range of 2.78-3.56 and a total grand mean of 3.34, polytechnic graduate have a mean range of $2.59-3.50$ and a total grand mean of 3.02 and College of education graduate have a mean range of 2.62-3.30 and a total grand mean of 3.05 which were above the bench mark of 2.50 that were regarded as agreed. Therefore all items under casual factors of unemployment among graduate of tertiary institutions in Nigeria were considered acceptable by the respondents.

\section{8. $\quad$ Research Question 2:}

What are the effects of unemployment on Graduates of tertiary institutions in Ogun State, Nigeria?

Table 2: Mean and Standard deviation on the Effects of Unemployment on graduates of tertiary institutions in Ogun State, Nigeria.

\begin{tabular}{|l|l|c|c|c|c|c|c|c|c|c|}
\hline & & \multicolumn{3}{|c|}{$\begin{array}{l}\text { University } \\
\text { Graduate }\end{array}$} & \multicolumn{3}{c|}{$\begin{array}{c}\text { Polytechnic } \\
\text { Graduates }\end{array}$} & \multicolumn{3}{c|}{$\begin{array}{c}\text { College of Education } \\
\text { Graduates }\end{array}$} \\
\hline S/N ITEMS & $\overline{\boldsymbol{X}}$ & SD & Decision & $\overline{\boldsymbol{X}}$ & SD & Decision & $\overline{\boldsymbol{X}}$ & SD & Decision \\
\hline 11 & Low self esteem & 2.67 & 0.69 & Agreed & 3.70 & 0.72 & Agreed & 2.20 & 0.40 & Agreed \\
\hline 12 & Feelings of depression & 3.77 & 0.42 & Agreed & 2.73 & 0.64 & Agreed & 1.88 & 0.96 & Disagreed \\
\hline 13 & Aggression & 2.36 & 0.48 & Disagreed & 3.22 & 0.96 & Agreed & 1.68 & 1.03 & Disagreed \\
\hline 14 & Rejection by relative and friend & 1.67 & 0.47 & Disagreed & 2.93 & 0.68 & Agreed & 1.55 & 0.96 & Disagreed \\
\hline 15 & $\begin{array}{l}\text { Indulgence in criminal activities (such as } \\
\text { armed robbery, kidnapping, militancy, } \\
\text { rape and ritual killing) due to frustration }\end{array}$ & 2.08 & 0.86 & Disagreed & 3.22 & 0.41 & Agreed & 2.53 & 0.50 & Agreed \\
\hline 16 & Indulgence in prostitution & 2.73 & 0.89 & Agreed & 2.68 & 1.38 & Agreed & 2.47 & 0.50 & Disagreed \\
\hline 17 & $\begin{array}{l}\text { Indulgence in crime using information and } \\
\text { communication technology (ICT) }\end{array}$ & 2.04 & 0.71 & Disagreed & 3.93 & 0.38 & Agreed & 3.45 & 0.50 & Agreed \\
\hline
\end{tabular}




\begin{tabular}{|l|l|c|c|c|c|c|c|c|c|c|}
\hline 18 & Delay in marriage & 1.67 & 0.47 & Disagreed & 2.94 & 1.35 & Agreed & 3.57 & 0.50 & Agreed \\
\hline 19 & 3.48 & 0.50 & Agreed & 1.36 & 0.98 & Disagreed & 3.60 & 0.49 & Agreed \\
\hline 20 & $\begin{array}{l}\text { Deprivation from socialization effect of } \\
\text { work }\end{array}$ & 3.07 & 0.44 & Agreed & 2.07 & 0.99 & Disagreed & 3.05 & 0.70 & Agreed \\
\hline & Total grand Mean & 2.55 & & Agreed & 2.88 & & Agreed & 2.60 & & Agreed \\
\hline
\end{tabular}

Table 2, revealed the effects of unemployment on graduates of tertiary institutions in Nigeria with a total grand mean of 2.55 for university graduates, 2.88 for polytechnic graduates and 2.60 for college of education graduates. The table indicated that university graduates agreed to items 11 , $12,16,19$ and 20 with a mean ranged of 2.67-3.77 which were above the benchmark of 2.50 and above. Items 13, 14, 15, 17 and 18 with a mean raged of 1.67-2.36 were disagreed that these are no effects of unemployment on graduates of tertiary institutions in Nigeria. The polytechnic graduates agreed to items $11,12,13,14,15,16,17$ and 18 with a mean ranged of 2.68-3.70 which were above the benchmark of 2.50 and above. Items 19 and 20 with a range of 1.36-2.07 were disagreed. The college of education graduates agreed to items 15, 17, 18, 19 and 20 with a mean range of 2.53-3.60 which were above the benchmark of 2.50 , while items $11,12,13,14$ and 16 with a mean ranged of $1.55-2.47$, were disagreed that these are no effects of unemployment on graduates of tertiary institutions in Nigeria.

\section{Hypothesis 1}

There is no significant difference among University, Polytechnic and College of Education graduates in their opinion about the effects of unemployment on graduates of tertiary institutions in Ogun State, Nigeria.

Table 3: One way analysis of variance among University, Polytechnic and College of Education graduates in their opinion about the effects of unemployment on graduates of tertiary institutions in Ogun State Nigeria.

\begin{tabular}{|l|c|c|c|c|c|}
\hline Source Of Variation & Sum of squares & Df & Mean Square & F & Sig \\
\hline Between groups & 769.738 & 2 & 384.869 & 81.958 & 0.000 \\
\hline With Groups & 1779.752 & 379 & 4.696 & & \\
\hline Total & 2549.490 & 381 & & & \\
\hline
\end{tabular}

Table 3, showed that the F-value of 81.958 and a P-value of 0.000 . testing the hypothesis at an alpha level of 0.05 the P-value of 0.000 was less than the alpha level of 0.05 . therefore the null hypothesis which states that "there is no significant difference among university, polytechnic and college of education graduates in their opinion about the effects of unemployment on graduates of tertiary institutions in Ogun State Nigeria was rejected. This implied that there is significant difference among university, polytechnic and colleges of education graduates in their opinion about the effects of unemployment on graduates of tertiary institutions in Ogun State Nigeria.

\section{Discussion}

The research has revealed that one of the causal factors of graduate unemployment of tertiary institutions in Ogun State, Nigeria is the high rate of graduates turnout with mean score of 3.69 which is above the bench mark of 2.50 on table one. This finding corroborate Sara (2008) and Tandama (2009) researches which revealed that the situation drastically became difficult as the number of graduates continue to soar, coupled with shortage of vacancies. Another finding of this research as a causal factor of graduate unemployment of tertiary institutions in Ogun State, Nigeria is the neglect of the agricultural sector by the Nigerian government as a result of over dependence on oil with mean score of 3.33 which is above benchmark of 2.50 on table one. This finding agrees with Adekola, et al (2016), who identified the neglect of agricultural sector as one of the causal factors of graduate unemployment of tertiary institution in Ogun State Nigeria. Adekola, et al stated 
that the dependence of Nigeria totally on oil sector has made the young graduates to migrate from the rural areas to urban centres where they could get employment in oil companies.

The research has also found out that another causal factor of graduate unemployment of tertiary institutions in Ogun State, Nigeria, is the collapse of manufacturing industries with a mean score of 3.46 which is above the benchmark of 2.50 on table one. This finding was in agreement with Adesina (2013), when he observed that over 800 industries collapsed in Nigeria and over 37 factories closed shops in 2009. Adesina added that half of the remaining operating firms have been classified by the Manufacturing Association of Nigeria (MAN) as "ailing" a situation that poses a great threat to the survival of manufacturing in Nigeria.

Another finding of this research with respect to the causal factor of graduate unemployment of tertiary institutions in Ogun State Nigeria, is the reform in the banking sector that has resulted into regular retrenchment of workers with a mean score of 3.07 which is above the benchmark of 2.50 on table one. This finding lays credence to the assertion of Adesina (2013) when he opined that the banking sub- sector had not help matter. This is because ongoing reforms and consolidation has sent several young men and women back into the labour market instead of the, banking sector generating employment.

The research has found out that one of the causal factors of graduate unemployment of tertiary institutions in Ogun State, Nigeria, is lack of employable skill by the graduates with a mean score of 3.56 which is above the benchmark of 2.50 on table one. This finding is in consonance with Shuib (2012), and Noor (2011) as quoted in Louge (2017), who found out that job mis- match, English proficiency, misguided educational qualification and lack of employable skills were held as factors responsible for university graduate unemployment in Ogun State, Nigeria.

This research has also found out that misappropriation of fund meant for development of projects is one of the causal factors of graduate unemployment of tertiary institution in Ogun State, Nigeria with a mean score of 2.78 which is above the benchmark of 2.50 on table one. This finding corroborates Okafor (2011), when he opined that corruption is one of the reasons responsible for unemployment in Nigeria. Okafor maintained that corruption has deprived Nigeria of developing a strong economic base. Okafor added that fund meant for development of projects have been misappropriated, diverted, embezzled and stashed away in foreign banks.

The research found out that one of the causal factors of graduate unemployment of tertiary institutions in Ogun State, Nigeria is because the curricular offered by them in their higher institutions were tailored towards white collar jobs with a mean score of 3.42 which is above the benchmark of 2.50 on table one. This finding gives credence to Sara and Mburza (2011) when they opined that the reasons why graduates find it difficult to secure jobs after graduation may be traced to inadequate curriculum adopted by their institutions. Sara and Mburza further claimed that graduates do not have appropriate job competencies required by their employers since curricular offered by them were tailored towards white collar jobs.

The research has revealed that some of the effects of graduate unemployment of tertiary institutions in Ogun State, Nigeria is the feeling of low self-esteem with a mean score of 2.69, feeling of depression with a mean score of 3.77 and aggression with a mean score of 2.36 which are above the benchmark of 2.50 on table two. These findings lay credence to Aihie and Alika (2014), when they stated that unemployment has negative effects on the unemployed such as low self esteemed frustration and depression.

The research has not found out that one of the effects of graduate unemployment of tertiary institutions in Ogun State, Nigeria is the rejection of such graduates by their relatives and friends with a mean score of 1.67 which is below the benchmark of 2.50 on table two. This finding disagreed with Asmara and Mulata (2014), who stated that the unemployed graduates are not socially recognized and this make friends and relations to look-down on them as liabilities in the society.

This research has not revealed that one of the effects of graduates unemployment of tertiary institutions in Ogun State, Nigeria, is their indulgence in criminal activities such as armed robbery, kidnapping, militancy, rape and ritual killings, due to frustration with a mean score of 2.08 which is below the benchmark of 2.50 on table two. This finding contradicts the opinion of Asmara and Mulate (2014), when they stated that unemployed graduates exhibit a kind of non- conforming and negative social vices that are found in Nigeria today, for example, kidnapping. 
The research has found out that one of the effects of graduates unemployment of tertiary institutions in Ogun State, Nigeria is their indulgence in prostitution with a mean score of 2.73 which is above the benchmark of 2.50 on table two. This finding lays credence to Aihie and Alika (2014), when they stated that unemployment may lead to anti- social behaviour such as prostitution in females.

This research has not revealed that graduate unemployment of tertiary institution in Ogun State, Nigeria is responsible for delay in marriage with a mean score of 1.67 which is below the benchmark of 2.50 on table two. The research found out that graduate unemployment of tertiary institution in Ogun State, Nigeria is responsible for economic hardship and deprivation from socialization effect of work with a mean score of 3.48 which is above the benchmark of 2.50 on table two. This finding agrees with Madoui (2015), when he asserted that the unemployed graduate is deprived of earning salary, he is equally deprived of work and removed from socialization ties and relationship.

The research found out on table three that there is significant difference among university, polytechnic and college of education graduates in their opinion about the effects of unemployment on graduates of tertiary institutions in Ogun State, Nigeria. The difference may due to different ways the three groups of graduates feel the effects of unemployment.

\section{Conclusion}

The conclusion that can be drawn as a result of the finding of the research is that, there is unemployment of graduates of tertiary institutions in Ogun State, South West, Nigeria. The causes of unemployment are, high rate of graduate turnout, neglect of the agricultural sector by the government, collapse of the manufacturing industries and lack of employable skills by graduates. The researcher also concluded that the unemployment has resulted in graduates having low self esteem, feeling of depression, aggression and indulgence in prostitution among the females.

\section{Recommendations}

As a result of the findings and conclusion reached, the following recommendations are proposed by the researcher.

1. Admission into tertiary institutions should be based on the number of vacancies available in public and private sectors.

2. Government should revive the agricultural sector and manufacturing industries to provide employment for the graduate of tertiary institutions.

3. Graduates of tertiary institutions should focus their studies on skills that are demanded by employers of labour.

4. Government should not engage in misappropriation of fund meant for developmental projects.

5. Graduates of tertiary institutions should try to perform well to pass employment interview.

6. Unemployed graduates of tertiary institutions should stop having wrong perception of selfemployment.

7. Unemployed graduates of tertiary institutions should not have low self- esteem of themselves, feeling of depression and should not be aggressive towards people.

8. Unemployed female graduates of tertiary institutions should not engage themselves in prostitution.

9. Government should pay a specified amount of money to all unemployed graduates of tertiary institutions in order to reduce their economic hardship.

\section{Counselling Implications}

The following are the implications of the study:

1. There is the need for state governments to establish counselling centres in all communities in their states and counsellors are to be employed to counsel unemployed graduates to change their irrationals thoughts or beliefs about securing only white collar jobs. 
2. The community counsellors are to reach out to pastors of different churches and Imams of Mosques to sensitize their members on the need to establish their own businesses.

3. Community counsellors are to liaise with Non- Governmental organisations (NGO) on the need to empower unemployed youths financially so that they can be self-employed and also to train these applicants to acquire the needed skills.

4. The Counselling Association of Nigeria (CASSON) at the National and state levels are to work hand in hand with various ministries and para-statal to organize lectures, seminars and conferences for unemployed graduates of tertiary institutions to disabuse their minds about continuously waiting for government jobs and setting up their own businesses.

5. The Counselling Association of Nigeria (CASSON) at the national level should work with curriculum planners of tertiary institutions so as to include more courses in entrepreneurial studies in the programme of students in order to make them imbibe the culture of self employment.

\section{References}

Adekola, P. O., Allen, A. A., Olawole, - Isaac, A., Akanbi, M. A. \& Adewumi, O. (2016). "Unemployment in Nigeria, a challenge of democratic change" International Journal of Scientific Research in Multidisciplinary Studies, 2(5).

Adesina, O. S. (2013). "Unemployment and security challenges in Nigeria" International Journal of Humanities and Social Sciences. 03(07).

Aihie, O. N. \& Alika, H. I. (2014). "Combating youth unemployment in Nigeria through effective school counselling". Edo Journal of Counselling. 201- 218.

Asika, N. (2002), Research Methodology in the behavioural sciences, Lagos: Longman, Nigeria Plc.

Balogun, K. (2016). Unemployment in Africa a paper presented at African transformation forum organized by Africa Centre for Economic Transformation (ACET)

Daily Trust Newspaper (2018). "Unemployment of graduates is Nigeria's biggest problem". (https://www.dailytrust.com.ng/)

Egwunyenga, E. J. (2018). In Yusuf and Afolabi (2014). "Tending the Ivory Tower Swimming against the tide" $63^{\text {rd }}$ in the series of Inaugural lecturers of the Delta State University, Abraka, Nigeria.

Longe, O. (2017). "Graduate unemployment in Nigeria: Causes, Consequences and remediable approaches". American International Journal of Contemporary Research. 7(4).

Madoui, M. (2015). Unemployment among young graduates in Algeria, a sociological readings: Open Journal of Social Sciences 3(1): Pp 35 - 41. Online: https://dixdolorol110. 4236jss 2015.31006.

Naong, M. (2011). "Promotion of Entrepreneurial education, a remedy to graduate and youth unemployment" Journal of Social Sciences. 28(3): Pp. 181-189.

Noor, I. G. (2011). "Graduate characteristics and unemployment, a study among Malaysians graduates", International Journal of Business and Social Sciences, 2(16).

Okafor, E. E. (2011). "Youth unemployment and implications for stability of democracy in Nigeria". Journal of Sustainable Development in Africa. 13(1).

Okiokio, F. (2012). Vocational guidance among youths, Warri COEUT Publishers Organisation for Economic Cooperation and Development (2002), The ins and outs of who is term unemployment. OECD Employment Outlook. Website:https://www.oecd.org/employment/empl17652683. Pdf retrieved on May 30, 2014.

Okpoko, I. U. \& Ughwufore, A. I. (2015). "Long-term unemployment and opinion of, the unemployed youths on adjustment strategies". The Counsellor, 34(1).

Sara, S. S. \& Mburza, A. (2011). Determinants of self-employment among unemployed graduates in Jigawa State. Implications for career development. Conference proceeding of National Conference of the Counselling Association of Nigeria (CASSON), Pp $11-20$.

Sara, S. S. (2008). "Evaluation of vocational training programmes among the in-mates of reformatory institutions in Jigawa State". Unpublished seminar paper submitted to the Department of Education, University of Maiduguri.

Sirat, M. \& Shuib, M. (2012). Employability in Malaysia, Bangkok and Thailand: Asian and Pacific Regional Bureau for Education UNESCO.

Taudama, A. M. (2009). "Significance of self-employment among unemployed graduates in Kaduna State", Unpublished PGDM Project report, department of Social Management Sciences, Bayero University, Kano. 